\title{
Pharmaceutical care in transplant patients in a university hospital: pharmaceutical interventions
}

\author{
Bruna Cristina Cardoso Martins ${ }^{1, *}$, Thalita Rodrigues de Souza $^{2}$, Ângela Maria Pita Tavares Luna ${ }^{3}$, \\ Marta Maria de França Fonteles, ${ }^{4}$ Paulo Yuri Milen Firmino ${ }^{4}$, Paula Frassinetti Castelo Branco \\ Camurça Fernandes ${ }^{5}$, José Huygens Parente Garcia ${ }^{6}$, Cláudia Maria Costa de Oliveira ${ }^{7}$, Eugenie \\ Desirèe Rabelo Néri ${ }^{8}$
}

\author{
${ }^{1}$ Multidisciplinary Residency in Transplantation, University Hospital Walter Cantídio, Fortaleza, CE, Brazil, ${ }^{2}$ Kidney \\ Transplant Unit, University Hospital Walter Cantidio, Fortaleza, CE, Brazil, ${ }^{3}$ Satellite Pharmacy of Surgical Stations, \\ University Hospital Wálter Cantídio, Fortaleza, CE, Brazil, ${ }^{4}$ Post-Graduation Program in Pharmaceutical Sciences, Federal \\ University of Ceará, Fortaleza, CE, Brazil, ${ }^{5}$ University Hospital Walter Cantídio, Fortaleza, CE, Brazil, ${ }^{6} H e a d$ of Liver \\ Transplant Unit, University Hospital Walter Cantídio, Fortaleza, CE, Brazil, ${ }^{7}$ Kidney Transplant Unit, University Hospital \\ Walter Cantídio, Fortaleza, CE, Brazil, ${ }^{8}$ University Hospitals of Federal University of Ceará, Fortaleza, CE, Brazil
}

\begin{abstract}
A descriptive and prospective study was conducted on the pharmaceutical care in the post-transplant outpatient clinic of Hospital Universitario Walter Cantidio of Universidade Federal do Ceará (HUWC/ UFC), in Fortaleza- Ceará in the period of April to October of 2011. The aim of the present study was to describe the pharmaceutical interventions performed in a Pharmaceutical Care service structured in the liver and kidney transplant outpatient clinic of an academic hospital. The Pharmaceutical interventions (PI) were classified according to Sabater et al.(2005), with significance based on Riba et al.(2000) and the Negative Outcomes associated with Medication (NOM) established at the Third Consensus of Granada. Statistical analyses were performed using the Epi Info v.3.5.1 program and hypothesis tests were done with the SigmaPlot v.10.0 program. A chi-squared $\left(\mathrm{X}^{2}\right)$ test was utilized for statistical analysis of the sample. A total of 97 patients were followed, where 54 problems related to medications were identified and 139 PI performed. The main PI were in education of the patient about treatment $(n=111 ; 80 \%)(p<0.05)$, while the significance of all interventions were appropriate, where $83.4 \%(n=116)$ of PI performed in the study period were shown to be "significant" $(\mathrm{p}<0.05)$. Through pharmaceutical care, the pharmacist is capable of monitoring the pharmacotherapeutic treatment and intervening when necessary, while being part of the multiprofessional team caring for the transplant patient.
\end{abstract}

Uniterms: Pharmaceutical care. Pharmaceutical interventions. Liver transplant/pharmaceutical interventions. Kidney transplant/pharmaceutical interventions. Patient safety. Pharmacotherapeutic treatment/monitoring.

Trata-se de um estudo de descritivo e prospectivo, realizado durante o atendimento farmacêutico nos ambulatórios de pós-transplante do Hospital Universitário Walter Cantídio da Universidade Federal do Ceará (HUWC/UFC), em Fortaleza-Ceará no período de abril a outubro de 2011. O presente trabalho objetiva apresentar as intervenções farmacêuticas realizadas em um serviço de Atenção Farmacêutica (ATENFAR) estruturado nos ambulatórios do transplante hepático e renal de um Hospital Universitário. As intervenções farmacêuticas (IF) foram classificadas de acordo com Sabater et al.(2005), a significância baseadas em Riba et al.(2000) e os Resultados Negativos associados a Medicamentos (RNM) fundamentados no Terceiro Consenso de Granada. As análises estatísticas foram realizadas no programa Epi Info v.3.5.1 e os testes de hipótese foram feitos no programa SigmaPlot v.10.0. O teste estatístico utilizado para análise da amostra foi o qui-quadrado $\left(\mathrm{X}^{2}\right)$. Foram acompanhados 97 pacientes, identificados 54 problemas relacionados aos medicamentos e realizadas 139 intervenções farmacêuticas. As principais IF realizadas foram na educação do paciente sobre o tratamento $(\mathrm{n}=111 ; 80 \%)(\mathrm{p}<0,05)$, já enquanto a significância todas as intervenções foram apropriadas, sendo que $83,4 \%(n=116)$ das IF

\footnotetext{
*Correspondence: B. C. C. Martins. Hospital Universitário Walter Cantídio, Universidade Federal do Ceará. Rua Capitão Francisco Pedro, 1290. Rodolfo Teófilo, 60430-370-Fortaleza-CE, Brasil.E-mail: bbrunacristina@hotmail.com
} 
realizadas no período do estudo mostram ser "significantes" $(\mathrm{p}<0,05)$. O farmacêutico, através do exercício da ATENFAR, é capaz de monitorar o tratamento farmacoterapêutico e intervir, quando necessário, integrando-se a equipe multiprofissional no cuidado ao paciente transplantado.

Unitermos: Atenção farmacêutica. Intervenção farmacêutica. Fígado/transplante/intervenção farmacêutica. Rim/transplante/intervenção farmacêutica. Paciente/segurança. Tratamento farmacoterapêutico/monitoramento.

\section{INTRODUCTION}

The history of organ transplantation in Brazil began 1960 s, when the first kidney transplant was performed in1964 in Rio de Janeiro. In 1985, the first liver transplant was successfully carried out in Hospital das Clínicas da Universidade de São Paulo (Borges et al., 2010). The state of Ceará featured prominently in the country when 1037 transplants were conducted in the period of January to November of 2011, including 218 renal and 131 liver transplants (Ceará, 2011). In all Brazil, Hospital Universitario Walter Cantidio holds third place in liver transplants, just behind Hospital Albert Einstein (SP) and Hospital das Clínicas da Universidade de São Paulo. The Renal Transplant Service of HUWC/UFC is also a pioneer in this area, since the first renal transplant in HUWC was performed in 1977, the first in Ceará and in the Northeast region (HUWC, 2011).

Liver transplant is indicated for patients who have advanced hepatic disease, since at this stage there are metabolic alterations, malnutrition, loss of muscle mass and function, respiratory alterations and other symptoms related to liver disease, where the combination of these factors interfere negatively with daily life activities and in the quality of life of these individuals (Barcelos et al., 2008). Renal transplant is one of the most recommended treatment and rehabilitation modalities for patients with chronic renal insufficiency, because it offers the patient a better quality of life, a possible reduction in risk of mortality, depending on the characteristics of the patient, and lower cost than dialysis. However, the choice for this type of treatment should take into account the individual characteristics of the patients, that is, demographic and co-morbidity factors, because each treatment modality has advantages and disadvantages (Cunha et al., 2007). After the transplant, the patient must adhere to a therapeutic regimen that includes taking immunosuppressants throughout life and frequent doctor visits and laboratory tests (Berquist et al., 2008). Non-adherence to treatment can result in graft rejection, which is a complicating factor in post-transplant care.

The transplant, although affording a better quality of life, demands a differentiated lifestyle in relation to eating, hygiene, medications and health precautions. A large portion of transplant patients, besides taking immunosuppressive drugs, concomitantly receive treatment for chronic diseases such as hypertension, diabetes and dyslipidemia and utilize prophylactic such as antibiotics, antifungals and antivirals. This polytherapy increases the risk of adverse reactions and drug interactions, besides difficulties in the utilization of medications (Wang et al., 2008).

A multidisciplinary approach is essential to guarantee adequate care of the transplant patient, particularly through the clinical duties of the pharmacist in the context of clinical pharmacy and pharmaceutical care. This can help reduce the risk of morbidities caused by pharmacotherapy, preventing treatment failure and complications of combined therapy (Hernanz, 2007).

Pharmaceutical care emerged from the development of clinical pharmacy practice, with the inclusion of a human component (Brasil, 2007). At the end of the 1980s, Hepler published a series of articles that established the necessity of changing the paradigm of professional pharmacy practice. These papers culminated in the publication of Opportunities and Responsabilities in Pharmaceutical Care (1990), which together with Strand, considered the beginning of a new paradigm - Pharmaceutical Care (Castro et al., 2006). The new professional practice led to closer relations between pharmacists and physicians, with the common objective of increasing the efficacy of drug treatment.

Systematic reviews report the positive findings with regard to the activities of clinical pharmacists in hospital teams (Kaboli et al., 2006; Wang, 2008). Pharmaceutical care practice demands that the professional takes part in a process in which he/she cooperates with the patient and other health care professionals, with the primary function of identifying drug-related problems (DRP), real or potential, as well as resolving the real ones and preventing the potential ones (Castro et al., 2006).

In Brazil, several studies involving Pharmaceutical Care for groups of patients with chronic diseases were conducted through the years. Many of them were able to show the benefits of this practice within the Brazilian health system, like the review realized by Simoni (2009), 
which showed that the process of solving Drug Related Problems in a Pharmaceutical Care service may aid the blood pressure control in non-controlled hypertensive individuals from community pharmacies. Besides, the meta-analysis conducted by Collins et al. (2011) and the study carried out by Lyra Jr et al. (2011) suggested that the pharmacist's intervention may be considered as a fundamental tool at the diabetes care and cardiovascular risk management.

Due to the benefits shown by the participation of the pharmacist on clinical and assistential level, the Pharmaceutical Care for special groups of patients/ users, especially in the SUS network, was included in the National Agenda of Science, Technology and Innovation for Health (Brasil, 2007). In 2001, a group of institutions concerned about the development of Pharmaceutical Care in Brazil constituted the Pharmaceutical Care Management Group under the coordination of the Pan-American Health Organization (PAHO). From the activities undertaken by this group resulted on a Brazilian Pharmaceutical Care Consensus proposal, being considered as it follows "a pharmaceutical practice model, developed in the pharmaceutical assistance context, which comprehends attitudes, ethical values, behaviors, skills, commitments and co-responsibilities at disease prevention, health promotion and recovery integrated with the professional health team.

Not all drug therapy problems can be identified from the medical prescription (Rovers, Currie, 2010). In pharmaceutical care, the pharmacist collects and organizes additional information to assure that the expected therapeutic outcome is achieved with the minimal occurrence of NOM. Through the practice of pharmaceutical care, the pharmacotherapeutic monitoring of patients is achieved and pharmaceutical interventions are performed, which are defined as all the activities in which the pharmacist actively participates, such as in decision making in the therapy of patients and also in the evaluation of results, thereby contributing to the increase in the efficacy of pharmacotherapy and decreasing its risks (Amaral, Amaral, Provin, 2008).

Drug Related Problems (DRP) were defined as any undesirable events experienced by the patient that involve or are suspected of involving medication and that interfere actually or potentially with an expected result in the treatment of the patient. Interference is not only limited to diseases and symptoms, but can also be any problem related to psychological, physiological, sociocultural or economic aspects. These DRP can cause or lead to the appearance of a NOM, where these effects on the health of the patient are not consistent with the objectives of the pharmacotherapy and are associated with the use of medications (Dader, Muñoz, Martinez-Martinez, 2008).

The selection of groups of patients is indispensable in Pharmaceutical Care, since it is not possible to analyze all the groups (Amaral, Amaral, Provin, 2008). The choice of target patients, which is, group of patients for whom the service is structured with the aim of carrying out necessary interventions, gives the pharmacist a greater impact in disease prevention and health promotion. This is done through counseling on the use of medications according to the desired results, with the purpose of reducing the occurrence of adverse reactions to medications and guaranteeing adherence to treatment (WHO, 2006). A study by Chisholm et al. (2001) showed that a multidisciplinary team approach that included a clinical pharmacist in the care of post-transplant patients was beneficial to improving their adherence to treatment.

The aim of the present study was thus to describe the pharmaceutical interventions performed in a pharmaceutical care service structured in the liver and kidney transplant outpatient clinic of an academic hospital in Ceará, Brazil, along with the pharmacoepidemiological profile of the patients seen in the service.

\section{MATERIAL AND METHODS}

A descriptive and prospective study was conducted during the pharmaceutical care of patients of the outpatient clinic for kidney and liver post-transplant care of Hospital Universitario Walter Cantidio da Universidade Federal do Ceará (HUWC/UFC), in the period of April to October of 2011. HUWC/UFC is a 243-bed academic hospital with broad specialized outpatient services and a complementary diagnostic services unit, which offers a high complexity level of tertiary health care.

The data were obtained from pharmacotherapeutic follow-up charts of patients seen at the kidney and liver transplant services, also with review of the patient's medical records. The pharmaceutical care service was realized by the resident pharmacists from the transplant area along with a pharmacist from the HUWC/UFC staff in the liver and kidney transplant ambulatory on a weekly basis. All patients who received care during the study period were selected P1 $2^{\circ}$ Revisor). The patients included in the study were receiving post-transplant ambulatory care, being selected, among them, those who received pharmaceutical care. Therefore, it was considered a convenience sampling technique. The follow-up of these patients was realized during the appointments with the pharmacists after being sent by the multi-professional health team. The patients were 
followed-up by the Dader method (Machuca, FernandezLlimos, Faus, 2003). During the study, the clinical activities (Pharmacotherapeutic follow-up, Identification of DRP and NOM, Pharmaceutical Intervention) were carried out by the pharmacist assigned to the kidney and liver transplant patients. Serum levels were recorded for immunosuppressants utilized by the transplant patients, that belonged to the class of calcineurin inhibitors or of mTor (mammalian target of rapamycin) inhibitors. Next, the post-transplant period of the patient was correlated with the serum immunosuppressant level, and comparison was made with the protocols established by the kidney and liver transplant team, to determine if the patient was within the level recommended for the period. The levels of calcineurin and mTor inhibitors are determined in the follow-up routine of patients and usually utilized in determining adherence to treatment in these patients. The determination of the serum level precedes each appointment scheduled with the physician, being used in this study, the mean value of the results on the pharmacist appointments.

Pharmaceutical interventions were classified according to Sabater et al. (2005) and categorized by significance ("significant," "very significant" and "extremely significant") according to Riba et al. (2000). In turn, the NOM followed the Third Consensus of Granada (2007) (Figure 1). The medications utilized by the patients seen by the service were classified according to the Anatomical Therapeutic Chemical (ATC) classification system (WHO, 2012).

The Epi Info v.3.5.1 program was used to perform the analyses of the data, and hypothesis tests were done with SigmaPlot v.10.0. A chi-squared $\left(\mathrm{X}^{2}\right)$ test was utilized for statistical analysis of the sample nominal variable. The level of significance considered for the comparative analyses was $p<0.05$. The observations of each variable were tabulated together with the presentation of the descriptive statistics of quantitative variables, which were presented graphically when convenient. In relation to the ethical aspects, the study was conducted in accordance with the Guidelines and Standards Regulating Research involving Humans and was approved by the Committee of Ethics in Research of HUWC/UFC under Protocol No.111.11.11.

\section{RESULTS}

A group of 97 post-transplant patients received pharmaceutical care during the study period. The patients were predominantly male $(58.8 \% ; n=57)$ with an age range of $41-60$ years $(40.3 \% ; n=39)$, where $35(n=36.1 \%)$ had

\section{NECESSITY}

-Untreated health problem: the patient suffers from a health problem associated with the lack of a needed medication; -Effect of unnecessary medication: the patient suffers from a health problem associated with taking a medication that is not needed.

\section{EFFECTIVENESS}

-Non-quantitative ineffectiveness: the patient suffers from a health problem associated with the non-quantitative ineffectiveness of the medication;

-Quantitative ineffectiveness: the patient suffers from a health problem associated with the quantitative ineffectiveness of the medication.

\section{SAFETY}

-Non-quantitative safety: the patient suffers from a health problem associated with a non-quantitative safety problem of the medication;

- Quantitative safety: the patient suffers from a health problem associated with a quantitative safety problem of the medication.

Source: research group in pharmaceutical care - Universidad de Granada (Spain).

FIGURE 1 - Classification of Negative Outcomes associated with Medication (NOM) according to the Third Consensus of Granada, 2007.

an incomplete primary education and $66(68 \%)$ patients were from other localities. A caretaker was involved in almost all cases $(n=85,87.6 \%)$. The majority of these caretakers had a complete secondary education $(42.4 \%$; $\mathrm{n}=36)$, and most were wives $(33 \% ; \mathrm{n}=28)$ (Table I).

In the analysis of pharmacotherapeutical profile of the medications utilized by the patients (Table II), during the at the end of the study period, the mean consumption of medications was 7 per patient, where there was a prevalence of antineoplastics and immunomodulators (Group L) ( $\mathrm{n}=194 ; 29.3 \%)$, followed by medications belonging to the group of general antibiotics for systemic use (Group J) $(\mathrm{n}=145 ; 22 \%)$ and medications for the digestive tract and metabolism (Group A) ( $\mathrm{n}=132 ; 20 \%)$.

\section{Anatomical Therapeutic Chemical (ATC)}

The serum level of immunosuppressants of the calcineurin inhibitor class associated with the posttransplant time of the patient showed that the patients who had a liver transplant and were in follow-up in the Pharmaceutical Care service were completing on average 5 months post-transplant and only $8.1 \%(n=3, p<0.05)$ had a tacrolimus level at variance with the protocol comparing the groups of patients divided according to 
TABLE I - Epidemiological characteristics of patients seen by the Pharmaceutical Care Service for kidney and liver transplant patients. April - October/2011, Fortaleza -Ceará

\begin{tabular}{ll}
\hline VARIABLE & $\mathbf{N}(\%)$ \\
\hline \multirow{2}{*}{ SEX } & Female $-40(41.2)$ \\
& Male $-57(58.8)$ \\
\hline & $<20$ years $-10(10.3)$ \\
& $20-40$ years $-27(27.8)$ \\
AGE & $41-60$ years $-39(40.3)$ \\
& $>60$ years $-21(21.6)$ \\
\hline
\end{tabular}

Illiterate - $9(9.3)$

Incomplete primary - $35(36.1)$

Complete primary - 12 (12.4)

EDUCATION

Incomplete secondary - 9 (9.3)

Complete secondary - 27 (27.8)

Incomplete higher - 1 (1.0)

Complete higher - 4 (4.1)

Fortaleza - 31 (32)

ORIGIN

Other - 66 (68)

Illiterate - $2(2,3)$

Incomplete primary - $17(20,0)$

Complete primary - $17(20,0)$

EDUCATION OF

CARETAKER

Incomplete secondary - $6(7,1)$

Complete secondary - $36(42,4)$

Incomplete higher - $1(1,2)$

Complete higher - $6(7,0)$

Wife - 28 (33)

Mother - 13 (15.3)

Daughter - 10 (11.7)

Sister - 6 (7.0)

Husband - 4 (4.7)

RELATION OF

Cousin - 4 (4.7)

CARETAKER

Niece - 4 (4.7)

Other - 8 (9.5)

Son - 2 (2.3)

Brother - 2 (2.3)

Sister-in-law - 2 (2.3)

Aunt - 2 (2.3)

the serum level, determined during the follow-up period. The post-kidney transplant patients were in the period of 6 months and all patients had a tacrolimus level in agreement with the service protocol in the follow-up period (Tables III and IV). During follow-up, five patients were on an mTOR inhibitor with a level of $6 \mathrm{ng} / \mathrm{mL}$ and with on
TABLE II - Medications utilized by the kidney and liver transplant patients seen by the Pharmaceutical Care service

\begin{tabular}{lcc}
\hline $\begin{array}{lcc}\text { MAIN ANATOMICAL GROUPS OF } \\
\text { ATC SYSTEM * }\end{array}$ & $\begin{array}{c}\text { ATC } \\
\text { CODE* }\end{array}$ & N (\%) \\
\hline Digestive tract and metabolism & A & $132(20)$ \\
Blood and hematopoietic organs & B & $32(5)$ \\
Cardiovascular system & $\mathbf{C}$ & $70(10.6)$ \\
Urogenital system and sex hormones & $\mathbf{G}$ & $3(0.4)$ \\
Hormones of systemic use, excluding & $\mathbf{H}$ & $79(12)$ \\
sex hormones & & \\
General antibiotics for systemic use & $\mathbf{J}$ & $145(22)$ \\
Antineoplastics and & $\mathbf{L}$ & $194(29.3)$ \\
immunomodulators & & \\
Musculoskeletal system & $\mathbf{M}$ & $1(0.1)$ \\
Central nervous system & $\mathbf{N}$ & $5(0.7)$ \\
\hline TOTAL & & $\mathbf{6 6 1 ( 1 0 0 )}$ \\
\hline April-October/2011, Fortaleza & &
\end{tabular}

April - October/2011, Fortaleza - Ceará.

average 8 months post-kidney transplant, in agreement with the service protocol.

A total of 54 DRP were identified, with $63.0 \%$ $(n=34)$ in post-kidney transplant and $20 \%(n=20)$ in post-liver transplant. From the identification of real and potential DRP, pharmaceutical interventions were performed to prevent possible NOM. The most common NOM (Figure 2) were related to untreated health problem $(\mathrm{n}=26 ; 48.1 \%)$ and quantitative ineffectiveness $(\mathrm{n}=10$; $18.5 \%)$. The most frequently used medications were involved with NOM: tacrolimus $(n=6 ; 11.1 \%)$; nystatin $(\mathrm{n}=5 ; 9.2 \%)$; and insulin, omeprazol, prednisone, and sulfamethoxazole+trimethoprim $(n=4 ; 7.4 \%)$.

During the study period, 139 pharmaceutical interventions (PI) were performed, mainly on the patient $(77 \% ; n=108)$, and of these interventions, $1.4 \%(n=2)$ were not accepted (Figure 3).

According to the classification by Sabater et al.(2005), the main interventions (Table V) were as follows: education of the patient regarding treatment $(\mathrm{n}=111 ; 80 \% ; \mathrm{p}<0.05)$, which showed greater statistical significance compared to the intervention groups, notably within this classification the interventions performed in treatment guidelines $(70 \% ; n=95 ; \mathrm{p}<0.05)$; dose of medication $(n=15 ; 11 \%)$ with greater frequency in the change in dosage of prescribed medication $(n=4$; $3 \%)$; and pharmacological strategy $(\mathrm{n}=13 ; 9 \%)$, with request for suspending unnecessary medication being the most frequent at $7 \%(n=10)$ (Table VI). With regard to significance, classified according to Farre et al., (não 
TABLE III - Serum levels of calcineurin inhibitor (Tacrolimus) of liver transplant patients seen by the Pharmaceutical Care Service. April - October/2011, Fortaleza - Ceará

\section{LIVER TRANSPLANT}

\begin{tabular}{cccc}
\hline TIME AFTER & $\begin{array}{c}\text { TACROLIMUS (mean value) } \\
\text { serum level, } \mathrm{ng} / \mathrm{mL})\end{array}$ & No. OF PATIENTS (\%) & $\begin{array}{c}\text { TACROLIMUS PROTOCOL } \\
\text { (serum level, } \mathrm{ng} / \mathrm{mL})\end{array}$ \\
\hline $2^{\text {nd }}$ month & 11 & $3(8.1)$ & $\mathbf{8}-\mathbf{1 0}$ \\
& & $\mathrm{p}<0.05, \mathrm{X}^{2}$ test & $\mathbf{6 - 8}$ \\
$3^{\text {rd }}-5^{\text {th }}$ month & 7 & $19(51.4)$ & $\mathbf{4 - 6}$ \\
$\geq 6$ months & 6 & $15(40.5)$ & \\
\hline
\end{tabular}

${ }^{1}$ Clinical protocols of liver transplant service of Walter Cantídio University Hospital - Federal University of Ceará.

TABLE IV - Serum levels of calcineurin inhibitor (Tacrolimus) of kidney transplant patients seen by the Pharmaceutical Care Service. April - October/2011, Fortaleza - Ceará

\begin{tabular}{cccc}
\hline & \multicolumn{2}{c}{ KIDNEY TRANSPLANT } & \\
\hline TIME AFTER & $\begin{array}{c}\text { TACROLIMUS } \\
(\text { serum level, ng/mL) }\end{array}$ & $\begin{array}{c}\text { No. OF PATIENTS } \\
(\%)\end{array}$ & $\begin{array}{c}\text { TACROLIMUS PROTOCOL } \\
\text { TRANSPLANT }\end{array}$ \\
\hline $1^{\text {st }}-2^{\text {nd }}$ month & 8 & $16(29.0)$ & $\mathbf{8 - 1 0}$ \\
$3^{\text {rd }}-6^{\text {th }}$ month & 6 & $21(38.2)$ & $\mathbf{6 - 8}$ \\
$7^{\text {th }}-12^{\text {th }}$ month & 6 & $15(27.3)$ & $\mathbf{5 - 7}$ \\
$>12$ months & 3 & $3(5.5 \%)$ & $\mathbf{3 - 5}$ \\
\hline
\end{tabular}

${ }^{2}$ Protocol of kidney transplant UNIT of Walter Cantídio University Hospital - Version 2011.

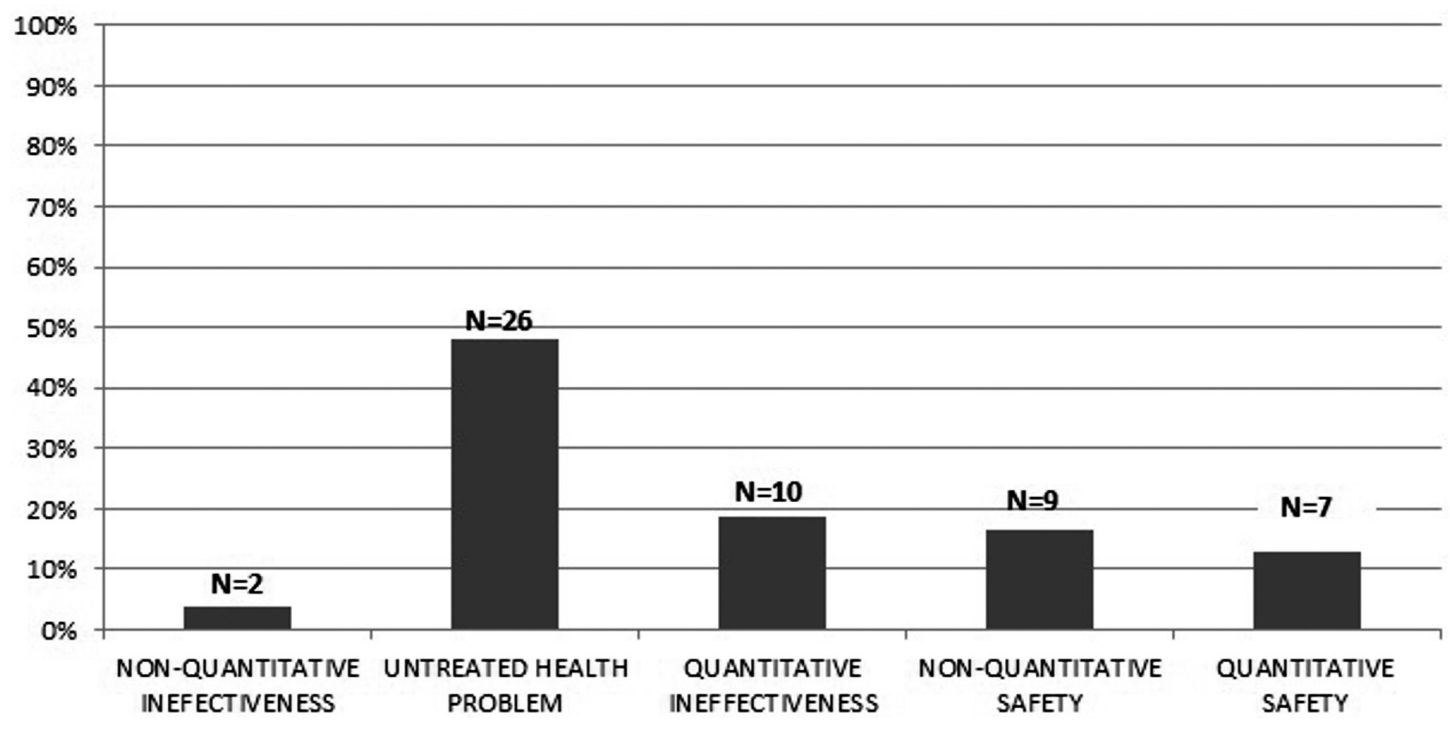

FIGURE 2 - Negative Outcomes associated with Medication (NOM) identified by the Pharmaceutical Care Service for kidney and liver transplant patients. April - October/2011, Fortaleza - Ceará. 


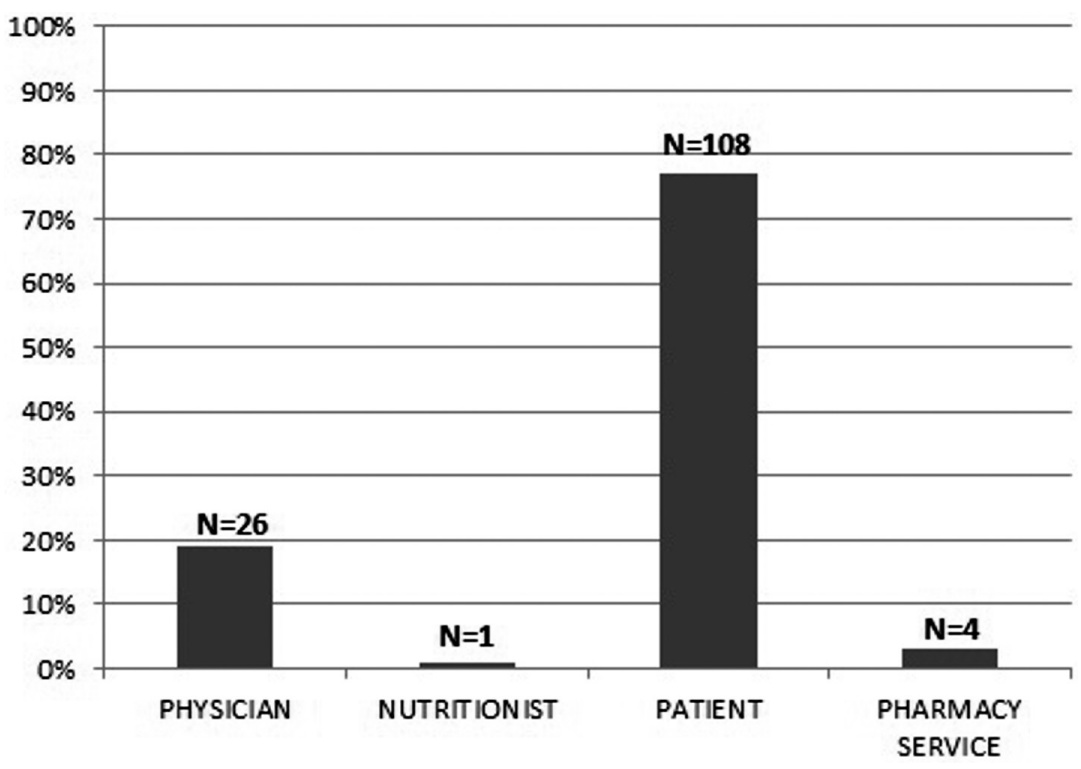

FIGURE 3 - Classes contacted in Pharmaceutical Interventions carried out by the Pharmaceutical Care Service for kidney and liver transplant patients in the period of April - October/2011 in Fortaleza - Ceará.

TABLE V - Classification according to Sabater et al. (2005) and Riba et al. (2000) of pharmaceutical interventions performed by the Pharmaceutical Care Service for kidney transplant patients in the period of April/2011 - October/2011 in Fortaleza - Ceará

\begin{tabular}{|c|c|c|c|}
\hline $\begin{array}{l}\text { Classification of PI types according } \\
\text { to Sabater et al. } .^{3}\end{array}$ & $\mathrm{n}(\%)$ & $\begin{array}{l}\text { Classification of significance of PI } \\
\text { according to Riba et al. }{ }^{3}\end{array}$ & $\mathrm{n}(\%)$ \\
\hline Intervention in education of patient on treatment & $111(80)$ & "Significant" & $116(83.4)$ \\
\hline Intervention in dose of medication & $15(11)$ & "Very significant" & $10(7.2)$ \\
\hline Intervention in pharmacological strategy & $13(9)$ & "Extremely significant" & $13(9.4)$ \\
\hline TOTAL & $139(100)$ & & $139(100)$ \\
\hline
\end{tabular}

${ }^{3} \mathrm{p}<0.05, \mathrm{X}^{2}$ test

TABLE VI - Pharmaceutical interventions ( $\mathrm{n}=139)(\mathrm{P} 8 \mathrm{a})$ performed bythe Pharmaceutical Care Service for kidney and liver transplant patients in the period of April - October/2011 in Fortaleza - Ceará

\section{PHARMACEUTICAL INTERVENTIONS}

Guidance on pharmacotherapeutic treatment

Request to suspend unnecessary medication

Adapt schedule of administration

Access of patient to pharmacological treatment

Guidance on the appropriate manner of administration of prescribed medication

Request to correct dose of prescribed medication

Request to change dosage of prescribed medication

Referral to nutritionist
$\mathrm{N}(\%)$

$\left(\mathrm{p}<0.05, \mathrm{X}^{2}\right.$ test $)$

$95(68)$

$10(7)$

9 (6)

$12(9)$

6 (4)

2 (1)

4 (3)

1 (1) 
consta nas References. Providenciar!) all interventions were "appropriate," where $83.4 \%(\mathrm{n}=116 ; \mathrm{p}<0.05)$ of pharmaceutical interventions performed in the study period were found to be "significant" (Table VI).

\section{DISCUSSION}

On analyzing the epidemiological profile of these patients, it was evident that there was a predominance of male patients, older than 40 years with incomplete primary education. It has been noted in the literature that age and level of education of patients who undergo chronic treatment influence adherence to the pharmacotherapy regimen instituted (Lima, Soler, Meiners, 2010). The education profile of the sample analyzed was similar to that of the study of Moreira (2008), in which the majority of patients with chronic renal disease interviewed were illiterate or had at most a primary education level (68.5\%). In the case of complicated treatment such as that in posttransplant, it is essential to have a caretaker with a more advanced level of education, but it is usually a family member who assumes this role. Thus, the role of the caretaker is strongly influenced by the degree of kinship and gender (Melo, Rodrigues, Schmidt, 2009).

The treatment instituted in liver and/or kidney post-transplant care is very complex, and in this study the patients needed to take on average seven different medications daily. As adherence to treatment is of utmost importance for the success of the transplant, it is necessary that these patients receive a specific care with adequate guidance. The utilization of many medications increases the chances of these patients developing adverse effects, as well as occurrence of drug interactions culminating in the abandonment of treatment and thus non-adherence (Schroeter et al., 2007).

The determination of blood immunosuppressant levels is important in the pharmacotherapeutic monitoring of transplant patients, because besides checking for toxic drug concentrations, it is also possible to monitor the patient's adherence to the treatment. In the study period, there were only three patients in the sample studied who did not show tacrolimus levels within those recommended in the protocol, which indicated statistical significance when compared to the other groups $(p<0.05)$. The routine monitoring of blood immunosuppressant levels aids in adjusting the dose to maintain the maximal efficacy with minimal toxicity (Brahm, 2012). It should be considered that some patients have an individual desired target, which can be below or above the range considered therapeutic. A study by Chisholm et al. (2001) showed that the group of post-renal transplant patients who received pharmacotherapeutic monitoring by a pharmacist had a greater adherence to treatment compared to the group of patients who did not receive such care.

The study conducted by Albert (2010), showed that a Pharmaceutical Care Program in which the clinical pharmacist worked together with a multidisciplinary team in the care of liver transplant patients allowed the identification, prevention and resolution of DRP, preventing adverse effects caused by pharmacotherapy and facilitating an appropriate guidance in the pharmacotherapy instituted. During the care of the patients by the Pharmaceutical Care service in a university hospital, guidance in the treatment instituted always paid close attention to the dose and schedule of administration of medications, but also identified NOM, which are effects on the health of the patient not adequately treated and which are associated with the use of medications; these NOM were determined by the existence of one or more DRP. The majority of interventions were done directly with the patient because they showed untreated health problems, where the interventions involved guidance in the treatment instituted, showing statistical significance compared to other interventions $(\mathrm{p}<0.05)$ the majority related to the access to the treatment and/or to nonadherence to the treatment.

Through pharmaceutical interventions, access of the patient to the treatment instituted was guaranteed, besides the assurance of its appropriate execution. The pharmacist of the Pharmaceutical Care service also performed important interventions when suspending unnecessary medications, always based on the protocol of two outpatient departments and clinical outcome of the patients and aimed at guaranteeing the rational use of medications. In relation to significance, a large portion of interventions were classified as "significant," because they were interventions that improved the care of the patient, resulting in enhanced quality of care. Still, some were classified as "extremely significant" because they were instrumental in a very important increase in efficacy or in quality of therapy, while others were categorized as "very significant" since they increased drug effectiveness or decreased toxicity, leading to an enhanced quality of life for the patient. In a study conducted in a post-kidney transplant unit in Georgia, $76.4 \%$ of pharmaceutical interventions were classified as "significant," where $28.6 \%$ were related to an untreated health problem and $26.6 \%$ to the dose of the medication (Chisholm, 2000).

Pharmaceutical Care encompasses all the activities conducted by the pharmacist assigned to the patient, with the objective of achieving the maximal benefit of the proposed pharmacotherapy, as well as promoting measures 
that improve health and prevent diseases (Dader, Muñoz, Martinez-Martinez, 2008).

\section{CONCLUSION}

The pharmacist of the Pharmaceutical Care service for the transplant patients was capable of carrying out interventions on the pharmacotherapy instituted, where these were for the most part "significant" by increasing the quality of care provided to the patient. Besides, the risks of the occurrence of negative outcomes associated with medication observed might be diminished, being considered a possible benefit from the pharmaceutical care service provided.

It is concluded that the pharmacist, through Pharmaceutical Care, provides guidance with respect to prescribed medications, monitors the pharmacotherapy, and intervenes when necessary, thereby establishing his/ her part in the multiprofessional team.

\section{REFERENCES}

AGUIAR, P.M.; BALISA-ROCHA, B.J.; BRITO GDE, C.; SILVA, W.B.; MACHADO, M.; LYRA JR., D.P. Pharmaceutical care in hypertensive patients: a systematic literature review. Res. Social Adm. Pharm., v.8, n.5, p.383$396,2012$.

ALBERT, A.R. Evaluación de un Programa de Atención Farmacéutica en pacientes sometidos a trasplante hepático. Pharm. care Esp., v.12, n.3, 2010, p.99-109.

AMARAL, M.F.Z.J.; AMARAL, R.G.; PROVIN, M.P. Intervenção farmacêutica no processo de cuidado farmacêutico: uma revisão. Rev. Eletr. Farm., v.5, n.1, p.60-66, 2008.

BARCELOS, S.; DIAS, A.L.; FORGIARINI-JÚNIOR, L.A.; MONTEIRO, B.M. Transplante hepático: repercussões na capacidade pulmonar, condição funcional e qualidade de vida. Arq. Gastroenterol., v.45, n.3, p.186-191, 2008.

BERQUIST, R.K.; BERQUIST, W.E.; ESQUIVEL, C.O.; COX, K.L.; WAYMAN, K.I.; LITT, I.F. Non-adherence to posttransplant care: prevalence, risk factors and outcomes in adolescent liver transplant recipients. Pediatr. Transplant., v.12, n.2, p.194-200, 2008.
BORGES, M.C.L.A.; BATISTA, M.O.R.; RODRIGUES, A.M.M.; CARVALHO, O.M.C. Transplante de fígado no Ceará caracterização da população atendida em 2007. $R$. Pesq.: Cuid. Fundam. Online, Brasil, suppl.2, p.5-7, 2010.

BRAHM, M.M.T. Adesão aos imunossupressores em pacientes transplantados renais. Porto Alegre, 2012. 102 p. [Dissertation of Master degree. Department of Medical Sciences, Federal University of Rio Grande do Sul].

BRASIL. Ministério da Saúde. Secretaria de Ciência, Tecnologia e Insumos estratégicos. Departamento de Assistência Farmacêutica e Insumos Estratégicos. A Universidade construindo o farmacêutico generalista para o SUS. In: Fórum Nacional de Ensino e as Pesquisa da Atenção Farmacêutica no Ambito do SUS, 1. Anais do $1^{\circ}$ Fórum nacional de ensino e pesquisa da atenção farmacêutica no âmbito do SUS "A universidade construindo o farmacêutico generalista para o SUS”. Brasília, 2007.

CASTRO, M.S.; CHEMELLO, C.; PILGER, D.; JUNGES, F.; BOHNEN, L.; ZIMMERMAN, L.M.; PAULINO, M.A.; JACOBS, U.; FERREIRA, M.B.C.; FUCHS, F.D. Contribuição da atenção farmacêutica no tratamento de pacientes hipertensos. Rev. Bras. Hipertens., v.13, n.3, p.198-202, 2006.

CEARÁ. Secretária da Saúde do Ceará (Org.). Ceará atinge pela primeira vez marca de 1.000 transplantes ano. Available at: <http://www.saude.ce.gov.br/index.php/ noticias/45032-Ceará-supera-pela-primeira-vez-marca-de1000-transplantes-ano->. Accessed on: Nov. 2011.

CHISHOLM, M.A.; VOLLENWEIDER, L.J.; MULLOY, L.L.; JAGADEESAN, M.; WADE, W.E.; DIPIRO, J.T. Direct patient care services provided by a pharmacist on a multidisciplinary renal transplant team. Am. J. Health Syst. Pharm., v.57, n.21, p.1599-1601, 2000.

CHISHOLM, M.A.; MULLOY, L.L.; JAGADEESAN, M.; DIPIRO, J.T. Impact of clinical pharmacy services on renal transplant patients' compliance with immunosuppressive medications. Clin. Transplant., v.15, n.5, p.330-336, 2001.

COLLINS, C.; LIMONE, B.L.; SCHOLLE, J.M.; COLEMAN, C.I. Effect of pharmacist intervention on glycemic control. Diabetes Res. Clin. Pract., v.92, n.2, p.145-152, 2010. 
COMITÉ DE CONSENSO GIAF-UGR, GIFAF-USE, GIFUGR. Tercer consenso de Granada sobre problemas relacionados con medicamentos y resultados negativos asociados a la medicación. Ars Pharm., v.1, n.48, p.5-17, 2007.

CUNHA, C.B.; LEÓN, A.C.P.; SCHRAMM, J.M.A.; CARVALHO, M.S; SOUZA JR, P.R.B.; CHAIN, R. Tempo até o transplante e sobrevida. Cad. Saúde Pública, v.4, n.23, p.805-812, 2007.

DÁDER, M.J.F.; MUÑOZ, P.M.; MARTINEZ-MARTINEZ, F. Problemas relacionados com medicamentos (PRM) e resultados negativos associados ao medicamento (RNM). In: DÁDER, M.J.F.; MUÑOZ, P.A.; MARTINEZMARTINEZ, F. (Eds.). Atenção farmacêutica: conceitos, processos e casos. Espanha:(Verificar cidade da Espanha com os autores) Ren Comercial e Editora, 2008. cap.2, p.49-59.

HERNANZ, B.C. Detección resultados negativos asociados a la medicación de pacientes de la Unidad de Observación del Área de Urgencias. Granada, 2007. 191 f. [Thesis of PhD degree. Faculty of Pharmaceutical Sciences, University of Gramado].

HOSPITAL UNIVERSITÁRIO WALTER CANTÍDIO (Brasil). Transplante. Available at: $<w w w . h u w c . u f c . b r>$. Accessed on: June 2012.

KABOLI, P.J.; HOTH, A.B.; MCCLIMON, B.J.; SCHNIPPER, J.L. Clinical pharmacists and inpatient medical care: a systematic review. Arch. Intern. Med., v.166, n.9, p.955964, 2006.

LIMA, T.M.; MEINERS, M.M.M.A.; SOLER, O. Perfil de adesão ao tratamento de pacientes hipertensos atendidos na Unidade Municipal de Saúde de Fátima, em Belém, Pará, Amazônia, Brasil. Rev. Pan-amaz. Saúde, v.1, n.2, p.113-120, 2010.

MACHUCA, M.; FERNÁNDEZ-LLIMÓS, F.; FAUS, M.J. Método dáder: guía de seguimiento fármacoterapéutico. Granada: GIAF-UGR, 2003. 128 p.

MELO, T.M.; RODRIGUES, I.G.; SHIMIDT, D.R.C. Caracterização dos cuidadores de pacientes em cuidados paliativos no domicílio. Rev. Bras. Cancerol., v.55, n.4, p.365-374, 2009.
MOREIRA, L.B.; FERNANDES, P.F.C.B.C.; MONTE, F.S.; MARTINS, A.M.C. Adesão ao tratamento farmacológico em pacientes com doença crônica. J. Bras. Nefrol., v.30, n.2, p.113-119, 2008.

RIBA, R.F.; ESTELA, A.C.; ESTEBAN, M.L.S.; CELS, I.C; LECHUGA, M.G.; SÁNCHEZ, S.L.; SANZ, R.T.; ARANDA, G.A.; ÁlVAREZ, F.C.; PELÁEZ, M.G.; ARCUSA, O.M.; SOLER, G.S.; MAZÓ, M.S. Intervenciones farmacêuticas (parte I): metodología y evaluación. Farm. Hosp., v.24, n.3, p.136-144, 2000.

ROVERS, J.P.; CURRIE, J.D. Guia prático da atenção farmacêutica: manual de habilidades clínicas. São Paulo: Pharmabooks, $2010.305 \mathrm{p}$.

SABATER, D.; FERNANDEZ-LLIMOS, F.; PARRAS, M.; FAUS, M.J. Tipos de intervenciones farmacéuticas en seguimiento farmacoterapéutico. Seguimiento(Autores providenciar nomenclatura) Farmacoterapéutico, v.3, n.2, p.90-97, 2005.

SCHROETER, G.; TROMBETTA, T.; FAGGIANI, F.T.; GOULART, P.V.; CREUTZBERG, M.; VEIGAS, K.; SOUZA, A.C.A.; CARLI, G.A.; MORRONE, F.B. Terapia anti-hipertensiva utilizada por pacientes idosos de Porto Alegre/RS, Brasil. Sci. Medica, v.17, n.1, p.14-19, 2007.

SIMONI, C.R. Avaliação do impacto de métodos de Atenção Farmacêutica. 2009. Porto Alegre, 2009. 183 f. [Dissertion of Master degree. Faculty of Pharmacy, Federal University of Rio Grande do Sul].

WANG, H.Y.; CHAN, A.L.F.; CHEN, M.T.; LIAO, C.H.; TIAN, Y.F. Effects of pharmaceutical care intervention by clinical pharmacists in renal transplant clinics. Transplant. Proc., v.40, n.7, p.2319-2323, 2008.

WORLD HEALTH ORGANIZATION. Anatomical Therapeutic Chemical (ATC). Available at: $<\mathrm{http}: / / \mathrm{www}$.whocc.no/ atc_ddd_index/>. Accessed on: Aug. 2012

WORLD HEALTH ORGANIZATION. Developing pharmacy practice: a focus on patient care: handbook, 2006. Available at: <http://www.fip.org/ files/fip/publications/DevelopingPharmacyPractice/ DevelopingPharmacyPracticeEN.pdf $>$. Accessed on: Sept., 2012. 